\title{
EEN EN ANDER OMTRENT ONZE \\ PREDIKANTEN TE SMIRNA IN DE 2E HELFT DER 17E EEUW, \\ DopR
}

W. F. VAN DAM VAN ISSELT.

Naar aanleiding van de noodzakelijkheid tot uitbreiding en verbetering van het Nederlandsche hospitasl te Smirna en den bouw van een nieuwe kerk aldaar, gaf eene Commissie uit onze kolonie te Smirna, die de voor de verbouwing en den bouw vereischte gelden hoopte bijeen te brengen, in Juli 1903 een oproep met roorafgaand goschiedkundig overzicht uit, getiteld: „De Nederlandsche Protestantsche Kerk en het Nederlandsch Nationaal Hospitaal te Smyrna". Voorzitter dier Commissie was onze toenmalige Consul-Generaal aldaar, Jhr. Mr. J. E. de Sturler, Secretaris-Penningmeester de Heer W. F. H. van der Zee.

Naar aanleiding van dit geschrift, en wellicht door enkele leden der Commissie beïnvloed, verschenen in de eerste jaren na 1903 in verschillende tijdschriften artikelen over onze zoo oude nederzetting in de Levant, onze kerk en ons hospitaal to Smirna. In het tijdschrift ${ }_{n} 0 p$ de Hoogte" van 1905 vindt men een uitroerige en levendige XIII. 
beschrijving van Smirna en zijn Hollandsche kolonie door Maurits Wagenvoort ${ }^{1}$ ). „Neerlandia” gaf in 1905, 1908 en 1910 verschillende artikelen over onze kolonie to Smirna en hare geschiedenis, den bouw en de inwijding van het gemoderniseerde Wilhelmina-hospitaal en de inwijding van het nieuwe kerkgebouw ${ }^{2}$ ). In laatstgenoemd jaar schreef Ds. M. A. Perk in „Gustaaf Adolf” een uitvoerige geschiedenis van onze kerk te Smirna ${ }^{3}$ ). Behalve aan het zooeven genoemde geschrift van De Sturler-Van der Zee, werd daartoe veel ontleend aan een „Notice sur l'Eglise Protestante Néerlandaise de Smyrne par le Consul R. J. van Lennep, datée de 1882", en opgenomen in het „Bulletin de la Commission de l'Histoire des Eglises Wallonnes", T. IV, 3ième livraison, 1890, blz. 253 en $\nabla$. Orer verschillende aanteekeningen en gegevens nopens onze kolonie te Smirna beschikkende, inzonderheid over het tijdrak van 1660 tot 1690 , omtrent betwelk alle gegevens te Smirna door de aardbeving aldaar van 1688 verloren zijn gegaan, acht ik het wel van belang om die, welke onze predikanten en de kerk te Smirna betreffen, hier kort mede te deelen, voor zoover zij strekken kunnen tot aanvulling van de hierróór genoemde geschriften, inzonderheid van het chronologisch ingerichte der Heeren Jhr. de Sturler en Van der Zee c.s.

Bij resolutie van de Staten-Generaal dd. 27 Maart 1660 werd Gerard Smits tot consul der Nederlandsche natie te Smirna benoemd. Hij was de tweede Hollandsche consul onzer Levantsche nederzetting - en niet de eerste, zooais het geschrift-De Sturler vermeldt - daar hï onzen eersten Hollandschen consul Michiel du Mortier, te voren koopman aldaar, opvolgde, die bij resolutie van Hunne Hoog Mog. dd. 8 Jan. 1657 was benoemd en den Griek Duca di

1) Op de hoogte, 1905, blz. 27, 89 en 153.

2) Neerlandia, 1905, blz. 221 en 229 (Maurits Wagenvoort); 1908, blz. 117 en 163 (beide over de inwijding van het Wilhelmina-hospitaal in de kerk te Smirna); 1910, blz. 70 (Ds. M. A. Perk).

3) Gustaaf-Adolf-vereeniging, 1910, blz. 69 e.v. Met 4 platen en bronnenopgave. 